\title{
MULTIPLE DRUG RESISTANT STAPHYLOCOCCUS AUREUS STRAINS ISOLATED FROM A FISH MARKET AND FROM FISH HANDLERS
}

\author{
Albuquerque, W.F. ${ }^{1}$, Macrae, A. ${ }^{2}$; Sousa, O.V. ${ }^{1}$ ' Vieira, G.H.F. ${ }^{3}$; Vieira, R.H.S.F. ${ }^{1}$ \\ ${ }^{1}$ Instituto de Ciências do Mar - LABOMAR, Universidade Federal do Ceará, Fortaleza, Ceará, Brasil; ${ }^{2}$ Instituto de Microbiologia \\ Professor Paulo Goes, Universidade Federal do Rio de Janeiro, RJ, Brasil; ${ }^{3}$ Departamento de Biologia da Universidade Estadual \\ Vale do Acaraú - UVA, CE, Brasil
}

Submitted: February 20, 2006; Returned to authors for corrections: July 13, 2006; Approved: January 18, 2007

\section{SHORT COMMUNICATION}

\begin{abstract}
The aim of this study was to investigate the presence of antibiotic resistant Staphylococcus aureus strains in fish stalls and in hands and nasal and oral cavities of fish handlers of the Mucuripe Fish Market, Fortaleza, Ceará, Brazil. All S. aureus isolates were resistant to Ampicillin and $44 \%$ were multi-drug resistant.
\end{abstract}

Key words: Fish products, Fish handlers, Antibiotic resistance, S. aureus

Fish meat has excellent nutritional value being rich in proteins, vitamins and unsaturated fatty acids. It is also extremely perishable and the safe consumption requires adequate sanitary conditions from the moment of catch, through preparation, sale and consumption $(7,8)$. In countries which keep adequate records of diseases transmitted through food, eating contaminated fish is responsible for a significant number of disease outbreaks (10). According to NG et al. (16), potentially pathogenic bacteria present in foods can reach high numbers without necessarily producing noticeable alterations in aspect, odour or taste. Presence of pathogens is difficult to detect and therefore good hygiene is of utmost importance. The quality and safety of fresh fish can be directly influenced by the lack of hygienic habits of fish handlers and contact with contaminated work surfaces, including benches, tables and unwashed knives.

Various factors pose a condition of risk to fish food safety and they range from contamination from the environment where it is caught up to contamination by the consumer before eating (20). Among the most frequent contaminating microorganisms are the coliforms, Escherichia coli, enterococci and Staphylococcus aureus, the latter representing a risk to health when enterotoxin responsible for food poisoning is produced (11). S. aureus is an etiological infection agent responsible for significant levels of morbidity and mortality. S. aureus is frequently cited in cases where resistance to antibiotic treatment has been reported (6). In an earlier study, Evangelista-Barreto and Vieira (5) found S. aureus in 60\% of the samples taken from the hands, nose and saliva from 60 fish food preparation workers. Some fish workers were found to be carriers of strains resistant to oxacillin and vancomycin, both of medical importance in the treatment of bacterial infections. Their study highlighted the need for a widespread survey of fish stalls and fish handlers to assess the frequency and distribution of antibiotic resistant $S$. aureus. The primary objective of this research was to isolate and identify antibiotic resistant $S$. aureus strains in two fish stalls (A and B) and handlers at the Mucuripe Fish Market, Fortaleza, Ceara, Brazil.

Samples for microbiological analysis were taken from two different work surfaces where fish were displayed and sold (stalls A and B) and from the hands, and nasal and oral cavities of two randomly selected fish handlers, one from each stall. Ten samples were taken from the work surfaces from each stall by rubbing a swab, moistened in $10 \mathrm{ml}$ Brain Heart Infusion (BHI medium - DIFCO), on a $30 \mathrm{~cm}^{2}$ area of each work surface. Swabs were then placed in a tube containing BHI liquid growth medium and the tube was then sealed until laboratory analysis.

*Corresponding Author. Mailing address: Av. da Abolição, 3207 - Meireles. Cep 60165-081 - Fortaleza, CE - Brasil. E-mail: regine@labomar.ufc.br ou reginevieira@terra.com.br 
From each of the two fish handlers, single samples were collected and processed in triplicate to detect and identify $S$. aureus. Material from the nasal cavities was obtained with the aid of a swab, moistened in $10 \mathrm{ml}$ of BHI, using light circular movements in each nostril. Material from hands was obtained by rubbing another swab in the inter-digital spaces, nails, palms and on the backs of hands. The oral material was collected using a third swab and circular movements on the tongue. Swabs were then placed in a tube containing BHI liquid medium and sealed. All samples were packed on ice and taken to the laboratory for analysis.

The BHI media with the swabs were diluted to $10^{-3}$ using $0.1 \%$ peptone water as the diluting agent. Aliquots of $0.1 \mathrm{ml}$ from each dilution were spread using a Drigalski loop onto the surface of Agar Baird Parker (ABP) medium in Petri dishes. The Petri dishes were inverted and incubated at $35^{\circ} \mathrm{C}$ for 48 hours. Three or four typical $S$. aureus colonies were selected from each Petri dish, transfered to BHI medium and incubated at $35^{\circ} \mathrm{C}$ for 24 hours. Aliquots were then transferred to Tryptone Soya Agar (TSA) medium and incubated at $35^{\circ} \mathrm{C}$ for 24 hours. Colonies were submitted to Gram staining, and those with morphological characteristics of $S$. aureus were submitted to the following biochemical tests: coagulase, catalase, thermonuclease (TNAse) and Manitol and Glucose (4).

Strains identified as $S$. aureus were suspended in $0.85 \%$ saline solution and spread on Mueller-Hinton agar Difco (MH), using sterile swabs. Standard antibiotic discs (CECOM) of ampicillim-10mcg (AMP), cephalothin-30mcg (CFL), chloramphenicol-30mcg (CLO) erythromycin-15mcg (ERY), lincomycin-2mcg (LIN), sulfamethoxazole-25mcg (SFT), oxacillin-1mcg (OXA) and vancomycin-30mcg (VAN) were then placed on top of the media and plates were incubated at $35^{\circ} \mathrm{C}$ for 16 to $18 \mathrm{~h}$. The diameters of the inhibition halos were measured with a pachymeter $(13,15)$.

Twelve strains were isolated from the benches at fish stalls $\mathrm{A}$ and $\mathrm{B}$ and fifteen strains were isolated from the fish handlers (six from nasal cavities, four from oral cavities and five from hands). All the hand samples (one from stall A and four from stall B) were resistant to AMP; one strain was also resistant to CLO and another to OXA. All strains isolated from the nasal cavities (five from stall A and one from stall B) were resistant to AMP. Of the five strains isolated from the nose of the handler from stall A, three were also resistant to LIN, two were resistant to ERY, one was also resistant to CLO and another to CFL. The strain isolated from the nose of the handler at stall B was resistant to AMP only. All strains isolated from the tongues of the fish handlers (three from stall $\mathrm{A}$ and one from stall B) were resistant to AMP; the isolate from the stall B handler was also resistant to CFL and OXA. All stall A strains were also resistant to LIN, two resistant to ERY and one CFL. All strains isolated from the hands of the fish handlers (one from stall A and four from stall B) were resistant to AMP; the stall A hand isolate was also resistant to CLO and one strain from the hands of the stall B worker was resistant to OXA. Strain resistance to antibiotics is summarized in Table 1.

These results support the findings of Evangelista-Barreto and Vieira (5) who observed that approximately $60 \%$ of 24 fish handlers from two fishmongers in Fortaleza were carriers of $S$. aureus either on their hands, nasal cavities or saliva. Brazilian literature on this subject also reports that large numbers of $S$.

Table 1. Antibiotic resistance profiles for Staphylococcus aureus strains isolated from two fish market workers and fish stalls.

\begin{tabular}{|c|c|c|c|c|c|}
\hline \multirow[t]{2}{*}{ Resistance profiles } & \multirow{2}{*}{$\begin{array}{l}\text { Number } \\
\text { of strains }\end{array}$} & \multicolumn{2}{|c|}{ Origin of strains } & \multirow[t]{2}{*}{$\%$} & \multirow{2}{*}{$\begin{array}{l}\text { Resistance } \\
\text { classification }\end{array}$} \\
\hline & & Workers & Stalls & & \\
\hline AMP & 14 & 8 & 6 & 51.85 & NMDR \\
\hline AMP, OXA & 1 & 1 & 0 & 3.70 & NMDR \\
\hline AMP, CLO & 1 & 1 & 0 & 3.70 & MDR \\
\hline AMP, LIN & 2 & 2 & 0 & 7.41 & MDR \\
\hline AMP,CFL,OXA & 1 & 1 & 0 & 3.70 & MDR \\
\hline AMP, ERY, OXA & 1 & 0 & 1 & 3.70 & MDR \\
\hline AMP,ERY,LIN & 2 & 0 & 2 & 7.41 & MDR \\
\hline AMP, CFL, ERY, OXA & 1 & 0 & 1 & 3.70 & MDR \\
\hline AMP, CFL, ERY, LIN & 1 & 1 & 0 & 3.70 & MDR \\
\hline AMP, CFL, LIN, OXA, SFT & 1 & 0 & 1 & 3.70 & MDR \\
\hline AMP, CLO, ERY, LIN & 1 & 1 & 0 & 3.70 & MDR \\
\hline AMP, CFL, ERY, LIN, OXA, SFT & 1 & 0 & 1 & 3.70 & MDR \\
\hline Total & 27 & 15 & 12 & 100.00 & \\
\hline
\end{tabular}

NMDR: non multidrug resistant, MDR: multidrug resistant; AMP: ampicillin, CFL: cephalothin; CLO: chloramphenicol; ERY: erythromycin; LIN: lincomycin, OXA: oxacillin; SFT: Sulfamethoxazole. 
aureus are isolated from utensils used for food processing $(3,18,21,22)$. In general, it would appear that there is a lack of training and / or care on the part of those who work with fish with regard to the risks associated with the widespread presence of antibiotic resistant pathogenic microorganisms. These reports indicate that Brazilian food safety legislation (1) is not being followed. Legislation recommends that all people who have contact with food be submitted to medical and laboratory examinations, that their state of health is analysed and that they use gloves

According to Tavares (19), the resistance to antibiotics, is explained not only by the presence of resistance genes but also by expression of these genes, which is controlled by the environment. The distribution of non-multidrug resistant (NMDR) and of multidrug resistant (MDR) S. aureus phenotypes is shown in Table 1. MDR strains were defined as being resistant to two or more chemicals from different antimicrobial classes $(9,17)$. Of the $27 \mathrm{~S}$. aureus isolated strains, $15(55.55 \%)$ were NMDR, with 14 resistant to ampicillin only. One MDR $S$. aureus strain was resistant to six antibiotics from four different antibiotic classes and was sensitive to chloramphenicol only. The MDR strains represented $44 \%$ of total number of $S$. aureus isolates (Fig. 1). These results are important because MDR $S$. aureus strains pose a threat to common antibiotic treatment for routine infections. The widespread presence of antibiotic resistant microorganisms highlights the importance of good hygiene practices in the fight against antibiotic resistant infectious agents. Resistance to a specific drug is often part of a larger package of resistance factors located on plasmids or transposons (2). More than $90 \%$

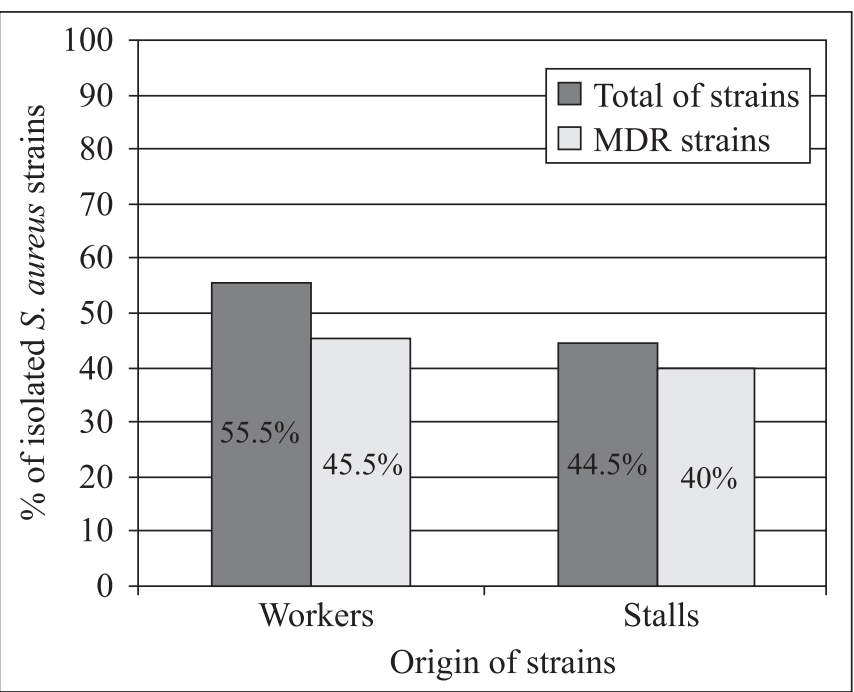

Figure 1. Percentage of multidrug resistant (MDR) and non multidrug resistant (NMDR) Staphylococcus aureus strains isolated from two fish market workers and fish stalls. of all $S$. aureus isolates studied in the United States and in Europe carried the $\beta$-lactamase gene (12). The stability of multidrug-resistant phenotype has been demonstrated in vitro over hundreds of generations of pneumococcal strains using non-selective media. Thus the issue is prevention of MDR $S$. aureus becoming infecting agents and not a change in drug use, meaning that regular inspections of the points of sale of fish are necessary in order to ensure good hygienic practices. The global spread of multidrug-resistant bacteria has increased in the past decade, thanks to the increased mobility of human populations (14). Greater public awareness of the presence of MDR S. aureus from non-hospital environments is needed and public awareness campaigns should be a priority to reinforce the importance of basic hygiene for food handlers, especially fish mongers.

\section{RESUMO}

\section{Multiresistência a antimicrobianos de cepas de Staphylococcus aureus isoladas de uma feira de pescado e de seus manipuladores}

O objetivo da pesquisa foi investigar a presença de Staphylococcus aureus resistente a antibióticos nos boxes de venda de peixe e nas mãos e cavidades nasal e oral de manipuladores de pescado da Feira de Pescado do Mucuripe, Fortaleza, Ceará. Todas as cepas isoladas foram resistentes à ampicilina e 44\% apresentaram multiresistência.

Palavras-chave: Produtos pesqueiros, manipuladores, resistência a antimicrobianos, Staphylococcus aureus

\section{REFERENCES}

1. AGÊNCIA NACIONAL DE VIGILÂNCIA SANITÁRIA - ANVISA Portaria $n^{\circ} 326$ de 30 de julho de 1997. Regulamento técnico sobre as condições higiênico-sanitárias e boas práticas de fabricação para os estabelecimentos produtores/industrializadores de alimentos. Diário Oficial [da] Repúblida Federativa do Brasil, Poder Executivo, Brasília, DF, 01 ago. 1997. Seção i, p.16.560-3.

2. Alterthum, F. (2004) In: Trabulsi, L.R.; Alterthum, F. (Eds). Microbiologia, Atheneu, São Paulo, p.84.

3. Ayulo, A.M.R.; Machado, R.A.; Scussel, V.M. (1994). Enterotoxigenic Escherichia coli and Staphylococcus aureus in fish and seafood from the southern region of Brazil. Int. J. Food Microbiol., 14: 687695.

4. Bennett, R.W. Staphylococcus aureus. In: FOOD AND DRUG ADMINISTRATION. Bacteriological analytical manual online. FDA/CFSAN, Jan. 2001. Disponível em: <http://www.cfsan.fda.gov/ ebam/bam-12.html>. Acesso em: 22 jul. 2003.

5. Evangelista-Barreto, N.S.; Vieira, R.H.S.F. (2003). Investigação sobre possíveis portadores de Staphylococcus aureus em duas indústrias de pesca. Higiene. Alimentar, 17: 49-57.

6. Farias, W.V.L.; Sader, H.S.; Leme, I.L.; Pignatari, A.C. (1997). Padrão de sensibilidade de 117 amostras clínicas de Staphylococcus aureus isolados em 12 hospitais. Rev. Assoc. Med. Brasil., 43:199-204 . 
7. Franco, B.D.G.M.; Landgraf, M. (1996). Microbiologia dos Alimentos. São Paulo: Atheneu, São Paulo, p.43-46.

8. Germano, P.M.L.; Miguel, M.; Miguel, O.; Germano, M.I.S. (1993). Prevenção e controle das toxinfecções de origem alimentar. Higiene. Alimentar., 7: 6-11.

9. Gibbs, S.G.; Green, C.F.; Tarwater, P.M.; Mota, L.C.; Mena, K.D.; Scarpino, P.V. (2006). Isolation of antibiotic-resistant bacteria from the air plume downwind of a swine confined or concentrated animal feeding operation. Environ. Health. Persp., 114: 1032-1037.

10. Hatha Mohamed, A.A.; Lakshmanaperumalsamy, P. (1997). Prevalence of Salmonella in fish and crustaceans from markets in Coimbatore, South India. Food Microbiol., 14:111-116.

11. International Commission Microbiological Specification for Food (ICMSF). (1978). Microorganisms in foods. $2^{\text {nd }}$ ed. Toronto: University of Toronto Press, Their significance and methods of enumeration. v.1.

12. Jabes, D.; Nachman, S.; Tomasz, A. (1989). Penicillin-binding protein families: evidence for the clonal nature of penicillin resistance in clinical isolates of pneumococci. J. Infect. Dis., 159: 16-25.

13. Koletar, S. (1995). L.Sthaphylococcus. In: Mahon, C.R.; Manuselis, G.Jr. (Ed). Textbook Diagnostic Microbiology. Editora Saunders Company, Philadelphia, cap.3, p.50-96.

14. Kunin, C. (1993) Resistance to Antimicrobial Drugs - A Worldwide Calamity. Ann. Intern. Med., 118: 557-561.

15. National Committee for Clinical Laboratorial Starndards-(NCCLS), (2005). Performance Standards for Antimicrobial Susceptibility Testing; Fifteenth Informational Suplement, v.25, n.1, M100-S14.
16. NG, S.P.; Tsui, C.O.; Roberts, D.; Chau, P.Y.; Ng, M.H. (1996). Detection and serogroup differentiation of Salmonella spp. in food within 30 hours by enrichment-immunoassay with a T6 monoclonal antibody capture enzyme-linked immunosorbent assay. Appl. Envir. Microbiol., 62: 2294-2302.

17. Rabatsky-Her, T.; Rossiter, J.W.; Holland, S.B.; Stamey, K.; Headrick, M.L.; Barrett, T.J.; Frederick, A.J. (2004). Multidrug-resistant Strains of Salmonella enterica Typhimurium,United States, 1997-19981. Emerg. Infect. Dis., 10: 795- 801.

18. Silva, Jr. E.A. (1993) Contaminação microbiológica como indicadora das condições higiênico-sanitárias de equipamentos e utensílios de cozinhas industriais, para determinação de pontos críticos de controle., São Paulo, 70p. (Tese de Doutorado. Instituto de Ciências Biomédicas, USP).

19. Tavares, W. (2000). Bactérias Gram-positivas problemas: resistência do estafilococo, do enterococo e do pneumococo aos antimicrobianos. Rev. Soc. Brasil. Med. Trop., 33: 281-301.

20. Vieira, R.H.S.F. (1989). Aspectos microbiológicos de pescado antes e depois de processado. In: Fonteles Filho, A.A.; Vieira, R.H.S.F. Ciência e tecnologia de produtos pesqueiros. Saint John's (Canadá): MUN Printing Services, v.1, p.1222-1272.

21. Vieira, R.H.S.F.; Tavares, L.A.; Gambar, R.C.; Pereira, M.L. (1998). $S$. aureus em camarão fresco e superfícies de bancada da feira livre de pescado do Mucuripe, Fortaleza, Ce. Registro de pontos críticos e medidas de controle. Higiene Alimentar., 12: 47-50.

22. Vieira, R.H.S.F.; Saker-Sampaio, S. (2004). Emprego do gelo nos barcos de pesca. In: Vieira, R.H.S.F. Microbiologia, Higiene e Qualidade do Pescado. São Paulo., cap. 2, 37-42. 